\title{
CONTEMPORARY CONCEPTS IN CARDIOLOGY
}

Pathophysiology and Clinical Management 
198. Antoine Lafont, Eric Topol (eds.): Arterial Remodeling: A Critical Factor in Restenosis. 1997 ISBN 0-7923-8008-8

199. Michele Mercuri, David D. McPherson, Hisham Bassiouny, Seymour Glagov (eds.): Non-Invasive Imaging of Atherosclerosis $\quad$ ISBN 0-7923-8036-3

200. Walmor C. DeMello, Michiel J. Janse(eds.): Heart Cell Communication in Health and Disease ISBN 0-7923-8052-5

201. P.E. Vardas (ed.): Cardiac Arrhythmias Pacing and Electrophysiology. The Expert View. 1998

ISBN 0-7923-4908-3

202. E.E. van der Wall, P.K. Blanksma, M.G. Niemeyer, W. Vaalburg and H.J.G.M. Crijns (eds.) Advanced Imaging in Coronary Artery Disease, PET, SPECT, MRI, I VUS, EBCT. 1998

ISBN 0-7923-5083-9

203. R.L. Wilensky (ed.) Unstable Coronary Artery Syndromes, Pathophysiology, Diagnosis and Treatment. 1998.

ISBN 0-7923-8201-3

204. J.H.C. Reiber, E.E. van der Wall (eds.): What's New in Cardiovascular Imaging? 1998

ISBN 0-7923-5121-5

205. Juan Carlos Kaski, David W. Holt (eds.): Myocardial Damage Early Detection by Novel Biochemical Markers. 1998.

ISBN 0-7923-5140-1

207. Gary F. Baxter, Derek M. Yellon, Delayed Preconditioning and Adaptive Cardioprotection. 1998.

ISBN 0-7923-5259-9

208. Bernard Swynghedauw, Molecular Cardiology for the Cardiologist, Second

Edition 1998.

ISBN 0-7923-8323-0

209. Geoffrey Burnstock, James G.Dobson, Jr., Bruce T. Liang, Joel Linden (eds): Cardiovascular Biology of Purines. 1998.

ISBN: 0-7923-8334-6

210. Brian D. Hoit, Richard A. Walsh (eds): Cardiovascular Physiology in the Genetically Engineered Mouse. 1998.

ISBN: 0-7923-8356-7

211. Peter Whittaker, George S. Abela (eds.): Direct Myocardial Revascularization: History, Methodology, Technology 1998.

ISBN: 0-7923-8398-2

212. C.A. Nienaber, R. Fattori (eds.): Diagnosis and Treatment of Aortic Diseases. 1999.

ISBN: 0-7923-5517-2

213. Juan Carlos Kaski (ed.): Chest Pain with Normal Coronary Angiograms: Pathogenesis, Diagnosis and Management. 1999.

ISBN: 0-7923-8421-0

214. P.A. Doevendans, R.S. Reneman and M. Van Bilsen (eds): Cardiovascular Specific Gene Expression. 1999

ISBN:0-7923-5633-0

215. G. Pons-Lladó, F. Carreras, X. Borrás, Subirana and L.J. Jiménez-Borreguero (eds.): Atlas of Practical Cardiac Applications of MRI. 1999 ISBN: 0-7923-5636-5

216. L.W. Klein, J.E. Calvin, Resource Utilization in Cardiac Disease. 1999.

ISBN:0-7923-8509-8

217. R. Gorlin, G. Dangas, P. K. Toutouzas, M.M Konstadoulakis, Contemporary

Concepts in Cardiology, Pathophysiology and Clinical Management.1999

ISBN:0-7923-8514-4

previous volumes are still available 


\section{CONTEMPORARY \\ CONCEPTS IN CARDIOLOGY \\ Pathophysiology and Clinical Management}

Richard Gorlin

George Dangas

Mount Sinai School

of Medicine, New York
Pavlos K. Toutouzas

M.M. Konstadoulakis

National University of Athens

School of Medicine

Foreword by

J. Willis Hurst

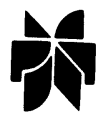

Springer Science+Business Media, LLC 


\section{Library of Congress Cataloging-in-Publication Data}

A C.I.P. Catalogue record for this book is available from the Library of Congress.

Themata sygchrones kardiologias. English. Contemporary concepts in cardiology: Pathophysiology and clinical management/[edited by] Richard Gorlin...[et al.] foreword by J. Willis Hurst.

P. Cm. --(Developments in cardiovascular medicine: 217) Includes index.

ISBN 978-1-4613-7274-5 ISBN 978-1-4615-5007-5 (eBook)

DOI 10.1007/978-1-4615-5007-5

1. Cardiovascular system--Diseases--Treatment. I. Gorlin, Richard, 1926- . II. Title. III Series: Developments in cardiovascular medicine : v. 217. [DNLM: 1. Cardiovascular Diseases--diagnosis. 2. Cardiovascular Diseases--physiopathology. 3. Cardiovascular Diseases--therapy, WG 120 T383 1999]. RC671.T47 1999 616.1--dc21 DNLM/DLC 99-26059 for Library of Congress

CIP

Copyright $(1999$ by Springer Science+Business Media New York Originally published by Kluwer Academic Publishers in 1999 Softcover reprint of the hardcover 1st edition 1999 All rights reserved. No part of this publication may be reproduced, stored in a retrieval system or transmitted in any form or by any means, mechanical, photocopying, recording, or otherwise, without the prior written permission of the publisher, Springer Science+Business Media, LLC, 
To our students and colleagues

R.G., P.K.T

To my parents and my associates

G.D.

To my parents

M.M.K 


\section{CONTEMPORARY CONCEPTS IN CARDIOLOGY}

Pathophysiology and Clinical Management

Foreword

xiii

J. Willis Hurst

Preface .......................................................................................... XV

George Dangas, Richard Gorlin

Prologue

xvii

Pavlos K. Toutouzas, Manoussos M. Konstadoulakis

\section{Section A \\ CORONARY ARTERY DISEASE}

\section{Chapter 1}

PATHOGENESIS OF ATHEROSCLEROSIS

Antonio Fernandez-Ortiz, Juan J Badimon, Valentin Fuster

Chapter 2

SYNDROMES OF ACCELERATED ATHEROSCLEROSIS 19

Beat Meyer, Lina Badimon, James H. Chesebro

\section{Chapter 3}

LIPOPROTEINS AND APOPROTEINS 28

Elena Citkowitz, Peter Herbert

\section{Chapter 4}

LIPID LOWERING THERAPY

Donald A. Smith

\section{Chapter 5}

SILENT MYOCARDIAL ISCHEMIA 102

Brian Schafer, Thomas C. Andrews, Peter H. Stone 
viii

\section{Chapter 6}

VASOSPASTIC ANGINA

Attilio Maseri, Gaetano A. Lanza

\section{Chapter 7}

THE ROLE OF NITRIC OXIDE IN CORONARY DISEASE 125

Todd J. Anderson, Ian T. Meredith, François Charbonneau, Peter Ganz, Andrew P. Selwyn

\section{Chapter 8}

THROMBOLYTIC AND ANTITHROMBOTIC THERAPIES

FOR ACUTE CORONARY SYNDROMES

Christopher P. Cannon, Joseph Loscalzo

\section{Chapter 9}

DEVELOPMENT OF COLLATERAL CORONARY CIRCULATION .....176 Olga Hudlicka, Margaret Brown

\section{Section B HYPERTENSION}

\section{Chapter 10}

INSULIN RESISTANCE, AND HYPERTENSION 195

Fred Slogoff, Eric Wasserman, Robert A. Phillips

\section{Chapter 11}

AMBULATORY BLOOD PRESSURE MONITORING

Peter A. Kringstein, Ethan D. Loeb, Robert A. Phillips

\section{Chapter 12}

ANGIOTENSIN CONVERTING ENZYME INHIBITORS

Theodore D. Mountokalakis

\section{Chapter 13}

DISTENSIBILITY OF THE GREAT VESSELS

AND HYPERTENSION

Christos Pitsavos, Christodoulos I. Stefanadis, Pavlos K. Toutouzas 


\section{Section C \\ CARDIOMYOPATHIES}

\section{Chapter 14}

PATHOPHYSIOLOGY AND MANAGEMENT OF HEART FAILURE ..249

Daniel Levy, George Dangas, Richard Gorlin

\section{Chapter 15}

HYPERTROPHIC CARDIOMYOPATHY

David P. Dutka, Celia M. Oakley

\section{Chapter 16}

DILATED CARDIOMYOPATHY

P. J. Keaning, William J. McKenna

\section{Chapter 17}

AUTOIMMUNE CARDIAC DISEASES 294

Manoussos M. Konstadoulakis, George D. Kymionis, Marina G. Toutouza, Emanuel Leandros

\section{Chapter 18}

CARDIAC TRANSPLANTATION

Ronald S. Freudenberger, Alan Gass

\section{Section D \\ CARDIAC GENETICS}

\section{Chapter 19}

DIFFERENTIAL GENE EXPRESSION IN MUSCLE

R. Sanders Williams

\section{Chapter 20}

GENETIC ANALYSIS OF CARDIOVASCULAR DISEASE 332

Ralph V. Shohet 
Chapter 21

GENETICS OF HYPERTROPHIC CARDIOMYOPATHY

Calum MacRae

\section{Chapter 22}

GENE THERAPY FOR CARDIOVASCULAR DISEASES

David W. M. Muller

\section{Section E \\ NONINVASIVE CARDIOLOGY}

\section{Chapter 23}

NUCLEAR IMAGING TECHNIQUES

Diwakar Jain, Barry L. Zaret

\section{Chapter 24}

ECHOCARDIOGRAPHY IN THE EVALUATION

OF CORONARY ARTERY DISEASE

Rebecca T. Hahn, Richard B. Devereux

\section{Chapter 25}

TRANSESOPHAGEAL ECHOCARDIOGRAPHY

Alan S. Katz

\section{Chapter 26}

DUPLEX VASCULAR ULTRASONOGRAPHY

Aris Antoniou, Lampros Vlahos

\section{Section F \\ INTERVENTIONAL CARDIOLOGY}

\section{Chapter 27}

TREATMENT OPTIONS FOR CORONARY

REVASCULARIZATION

Roxana Mehran, Martin B. Leon 


\section{Chapter 28}

CORONARY ATHERECTOMY

Samin K. Sharma, Annapoorna S. Kini

\section{Chapter 29}

EXCIMER LASER ANGIOPLASTY

Henry S. Ting, Farris K. Timimi, John A. Bittl

\section{Chapter 30}

NOVEL INTERVENTIONAL TECHNIQUES

FOR ACUTE CORONARY SYNDROMES

David R. Holmes, Jr., Robert S. Schwartz

\section{Chapter 31}

INTRACORONARY ULTRASOUND

George Dangas, Paul G. Yock

\section{Chapter 32}

RESTENOSIS

George Dangas, Roxana Mehran

\section{Chapter 33}

BALLOON MISTRAL VALVULOPLASTY

Christodoulos I. Stefanadis, Pavlos K. Toutouzas

\section{Section G \\ ELECTROPHYSIOLOGY}

\section{Chapter 34}

PHARMACOLOGIC THERAPY OF ARRHYTHMIAS 559

John Kassotis, Roy Sauberman, James Coromilas

\section{Chapter 35}

ABLATIVE THERAPY FOR ARRHYTHMIAS 
xii

Chapter 36

IMPLANTABLE CARDIOVERTER-DEFIBRILLATORS ..........................619

Leslie J. Lipka, James Coromilas

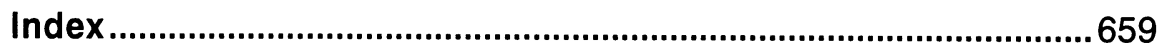




\section{FOREWORD}

This book, "Contemporary Concepts in Cardiology", has been created by a superb group of editors including Richard Gorlin and George Dangas form New York, and Pavlos K. Toutouzas and M.M. Konstadoulakis from Athens.

Aside from its scientific merit, the book will serve as tribute to Professor Richard Gorlin, whose death occurred before the book reached the bookselves of the readers. Gorlin taught us all the importance of learning the pathophysiologic mechanisms that are responsible for clinical conditions. Simply stated, he believed the art of medicine was improved if one understood why things happened. The legendary Gene Stead wrote why he and his associates perceived his teacher Soma Weiss as a great man. One reason he gives was, "his forte was to elicit the symptoms and signs and to relate them to pathophysiology." (Essays by E.A. Stead Jr. A way of thinking: a primer on the art of being a doctor. Edited by B.F. Haynes. Durham: Carolina Academic Press 1995: 65).

This book deals with contemporary concepts, and it is not presented as a complete treatise on cardiovascular problems. Rather it deals with current issues in which considerable progress and new insights are being developed. The book has been divided into seven sections: Coronary Artery Disease, Hypertension, Cardiomyopathies, Cardiac Genetics, Non-invasive Cardiology, Interventional Cardiology, and Electrophysiology. Each of the chapters leads the reader into a deeper understanding of the subject. Soma Weiss would, I believe, enjoy this book.

The editors and authors have done an excellent job in selecting and discussing the subjects that are currently being investigated and in which a conceptual understanding will improve the function and wisdom of the physician who studies their words.

J. Willis Hurst, MD

Consultant to the Division of Cadiology Professor and Chairman, Emeritus, Department of Medicine

Emory University School of Medicine Atlanta, Georgia, USA 


\section{PREFACE}

In the era of instant global communication, medicine is an international discipline characterized by a wide range of patient referral systems, world-wide discussion of clinical and research findings, and an explosion in the medical literature. Perhaps no field has progressed more than cardiology in the past few years.

The present text has been conceived as a supplement to the classic cardiology textbooks for the use of practicing physicians, cardiologists-intraining, medical students, and research investigators. We focus on associations between refinements in the understanding of disease and clinical applications. The material is presented in a way that limns the latest advances and focuses thinking towards future developments in cardiology.

We assembled a respected international panel of contributors so that each chapter is authored by a well-known specialist in his or her field. Every attempt was made to avoid the fragmentation which often characterizes the digest approach. Because the constant flow of information makes it nearly impossible to construct a timely book on advances in cardiology, the included chapters that describe the current concepts in cardiology and their underlying rationale, rather than attempting a comprehensive review of the most recent papers in each discipline. As new work emerges, it should fit into the overall blueprint.

This book would not have been possible without the help of many people. First, we thank the editorial team of the University of Athens for their collaboration. Next, we recognize the authors for their willingness to participate in this task and for their concise contributions. Thanks are also due to Karen Sadock, A.B., M.Div., for expert editorial review, and to I. Tiernan and M. Healy from the New York team, as well as to V. Kalaitzi and S. Tapa from the Athens team for their assistance. Finally, we acknowledge Melissa Ramondetta and Margarita Papailiou on behalf of the publishers.

George Dangas, Richard Gorlin Mount Sinai School of Medicine, New York 


\section{PROLOGUE}

We live in an era that Cardiology is punctuated by the rapid expansion of its scientific base; new technology and an availability of diagnostic and therapeutic modalities have never previously benn encountered.

In this book we attempt to describe the important changes of the cardiology within the last couple of years. The advances made in cardiology are reviewed by the pioneers of this field. Thorough analyses of the results of national and international trials, on hypertension and hyperlipidemias are analyzed and evaluated.

Normal cardiovascular function are affected profoundly by a large number of processes at the molecular and genetic lever that are now being understood. It is becoming clear that these abnormalities are the basis of many cardiovascular diseases. Research in the genetics of many diseases has been given added impetus by the increasing likelihood tha gene therapy will become a realistic therapeutic option. For this reason, in this book, special emphasis is given on Molecular Cardiology and its potential application on prevention, diagnosis and therapy.

We dedicate this book to every physician and we believe that it comes to fill a gap in the current literature, emphasizing a possible victory of noninvasive cardiology, which seems to be ready for the challenge of the year 2000 .

Pavlos K. Toutouzas, M.M. Konstadoulakis National University of Athens School of Medicine Athens, Greece 


\section{CONTRIBUTING AUTHORS}

Todd J. Anderson, MD, F.R.C.P.(C)

Assistant Professor of Medicine

Alberta Heritage Foundation for Medical Research

Foothills Hospital, University of Calgary Calgary, CANADA

Thomas C. Andrews, MD

Assistant Professor of Medicine

University of Texas

Southwestern Medical Center

Dallas, TX, USA

\section{Aris Antoniou, MD}

Assistant Professor of Radiology

University of Athens School of Medicine

Aretaieion University Hospital

Athens, GREECE

\section{Lina Badimon, PhD \\ Professor of Medicine and Cardiology \\ University of Barcelona \\ School of Medicine \\ Barcelona, SPAIN}

Juan J. Badimon, PhD

Associate Professor of Medicine

Director, Cardiovascular Research

Laboratories

Cardiovascular Institute

Mount Sinai School of Medicine

New York, NY, USA

\section{John A. Bittl, MD}

Ocala Heart Institute

Florida, USA

\section{Dr Margaret Brown}

Department of Physiology

University of Birmingham

School of Medicine

Birmingham, UK

\section{Christopher P. Cannon, MD}

Assistant Professor of Medicine

Harvard Medical School

Cardiovascular Division

Brigham \& Women's Hospital

Boston, MA, USA
François Charbonneau, MD, F.R.C.P.(C)

Assistant Professor of Medicine

Cardiovascular Division

Montreal Heart Institute

McGill University

Montreal, Quebec, CANADA

James H. Chesebro, MD

Professor of Medicine

Director of Clinical Research

Cardiovascular Institute

Mount Sinai School of Medicine

New York, NY, USA

\section{Elena Citkowitz, MD, PhD}

Director, Lipid Clinic and

Cardiac Rehabilitation

Hospital of St. Raphael

Assistant Clinical Professor of Medicine Yale University School of Medicine New Haven, NY, USA

James Coromilas, MD

Assosiate Professor of Clinical Medicine

Director, Electrophysiology Laboratory

Columbia University,

College of Physicians \& Surgeons

New York, NY, USA

\section{George Dangas, MD}

Consultant Cardiovascular Institute

Mount Sinai Medical Center

Mount Sinai School of Medicine

New York, NY, USA

Richard B. Devereux, MD

Professor of Medicine,

Division of Cardiology

Director, Echocardiography Laboratory

The New York Hospital-

Cornell Medical Center

New York, NY, USA

David P. Dutka, DM, MRCP

Department of Medicine

(Clinical Cardiology)

Royal Postgraduate Medical School

Hammersmith Hospital,

London, UK 
Antonio Fernandez - Ortiz, MD, PhD

Assistant Professor of Medicine

Hospital Universitario San Carlos

Madrid, SPAIN

Ronald S. Freudenberger, MD

Assistant Professor of Medicine

Director, Transplant Cardiology

University of Maryland

School of Medicine

Baltimore USA

\section{Valentin Fuster, MD, PhD}

Richard Gorlin, MD/Heart Research

Foundation Professor of Cardiology

Dean of Academic Affairs, Mount Sinai

Medical School

Director, Cardiovascular Institute

Mount Sinai Medical Center

New York, NY, USA

\section{Peter Ganz, MD}

Assosiate Professor of Medicine

Harvard Medical School

Associate Director, Cardiac

Catheterization Laboratory

Brigham \& Women's Hospital

Boston, MA, USA

\section{Alan Gass, MD}

Assistant Professor of Medicine

Director, Transplant Cardiology Section

Cardiovascular Institute

Mount Sinai Medical Center

New York, NY, USA

\section{J. Anthony Gomes, MD}

Professor of Medicine

Director, Electrophysiology Section

Cardiovascular Institute

Mount Sinai Medical Center

New York, NY, USA

Richard Gorlin, MD (1925-1997)

Dr. George Baher Professor of Medicine

Senior Vice President

Mount Sinai Medical Center

New York, NY, USA
Rebecca T. Hahn, MD

Assistant Professor of Medicine

Assistant Director,

Echocardiography Laboratory

The New York Hospital-

Cornell Medical Center

New York, NY, USA

Peter N. Herbert, MD

Clinical Professor of Medicine

Yale University School of Medicine

Chairman, Department of Medicine

Hospital of Saint Raphael

New Haven, CT, USA

David R. Holmes, Jr., MD

Professor of Medicine Mayo Medical School

Director, Adult Cardiac Catheterization Laboratory

Mayo Clinic and Mayo Foundation

Rochester, MN, USA

\section{Dr. Olga Hudlicka}

Professor and Head,

Department of Physiology

University of Birmingham

School of Medicine

Birmingham, UK

\section{Diwakar Jain, MD}

Assistant Professor of Medicine

Division of Cardiovascular Medicine

Yale University School of Medicine

New Haven, CT, USA

\section{John Kassotis, MD}

Section of Electrophysiology,

Division of Cardiology

Columbia University

College of Pysicians \& Surgeons

New York, NY, USA

Alan S. Katz, MD

Assistant Professor of Medicine

Brown University School of Medicine

Director of Echocardiography,

The Miriam Hospital

Providence, RI, USA 
Philip J. Keeling, MD, MRCP

Senior Registrar in Cardiology

St George's Hospital Medical School

London, UK

Annapoorna S. Kini, MD

Cardiovascular Institute

Mount Sinai Medical Center

New York, NY, USA

Manoussos M. Konstadoulakis, MD

Molecular Immunology Laboratory

Hippokrateion University Hopital

University of Athens School of Medicine

Athens, GREECE

Peter A. Kringstein, MD

Hypertension Section,

Cardiovascular Institute

Mount Sinai Medical Center

New York, NY, USA

George D. Kymionis, MD

Molecular Immunology Laboratory

Hippokrateion University Hospital

University of Athens School of Medicine Athens, GREECE

Gaetano A. Lanza, MD

Department of Cardiology

Catholic University of Rome

Rome, ITALY

Emanuel Leandros, MD

Assistant Professor

Department of Surgery

National University of Athens

Athens, GREECE

Martin B. Leon, MD

Director,

Cardiology Research Foundation

Washington Hospital Center

Clinical Professor of Medicine

Georgetown University

Washington, DC, USA

Daniel K. Levy, MD

Cardiovascular Institute

Mount Sinai Medical Center

New York, NY, USA
Leslie J. Lipka, MD, PhD

Instructor in Clinical Medicine,

Division of Cardiology

Columbia University,

College of Physicians \& Surgeons

New York, NY, USA

Ethan D. Loeb, MD

Hypertension Section,

Cardiovascular Institute

Mount Sinai Medical Center

New York, NY, USA

Joseph Loscalzo, MD, PhD

Whitaker Professor of Medicine and

Biochemistry

Boston University School of Medicine

Director, Whitaker Cardiovascular

Institute

Vice-Chairman, Department of Medicine

Chief, Cardiology Section

Boston University Medical Center

Boston, MA, USA

\section{Calum MacRae, MD}

Department of Genetics

Harvard Medical School

Boston, MA, USA

Attilio Maseri, MD

Professor of Cardiology

Director, Department of Cardiology

Catholic University of Rome

Rome, ITALY

William J. McKenna, MD

Professor of Cardiac Medicine

Department of Cardiological Sciences

Saint George's Hospital Medical School

London, UK

Roxana Mehran, MD

Director, Clinical Research and Data

Coordinating Center

Cardiology Research Foundation

Washington Hospital Center

Washington, DC, USA

Davendra Mehta, MD, PhD

Assistant Professor of Medicine

Mount Sinai School of Medicine

Director of Electrophysiology

Bronx VA Medical Center

New York, NY, USA 
Ian T. Meredith, M.B.B.S., Ph.D.

Deputy Director, Vascular Medicine and Hypertension

Monash Medical Center

Melbourne, AUSTRALIA

\section{Beat J. Meyer, MD}

Assistant Professor of Medicine Cardiac Catheterization Laboratory University Hospital Inselspital

Bern, SWITZERLAND

Theodore D. Mountokalakis, MD

Professor and Chairman

Department of Internal Medicine

Sotiria Univeristy Hospital

National University of Athens

Athens, GREECE

\section{David W.M. Muller, MBBS}

Professor of Medicine

Director, Cardiac Catherization Laboratories

St. Vincent's Hospital Center

Sydney, AUSTRALIA

Celia M. Oakley, DM, FRCP

Professor of Cardiology

Hammersmith Hospital

Royal Postgraduate Medical School London, UK

Robert A. Phillips, MD, PhD

Assosiate Professor of Medicine Director, Hypertension Section

Cardiovascular Institute

Mount Sinai Medical Center

New York, NY, USA

\section{Christos Pitsavos, MD}

Assistant Professor of Cardiology

Department of Cardiology

Hippokrateion University Hospital

National University of Athens

Athens, GREECE

\section{Roy Sauberman, MD}

Section of Electrophysiology,

Division of Cardiology

Columbia University,

College of Pysicians \& Surgeons

New York, NY, USA

\section{Brian Schafer, MD}

Cardiovascular Division

Wilford Hall Medical Center

San Antonio, TX, USA

Robert S. Schwartz, MD

Professor of Medicine, Mayo Medical School

Division of Cardiovascular Diseases and Internal Medicine

Mayo Clinic and Mayo Foundation

Rochester, MN, USA

\section{Andrew P. Selwyn, MD}

Professor of Medicine

Harvard Medical School

Director, Cardiac Catheterization Laboratory

Brigham \& Women's Hospital

Boston, MA, USA

Samin K. Sharma, MD

Assistant Professor of Medicine

Director, Cardiac Catheterization Laboratory

Cardiovascular Institute

Mount Sinai Medical Center

New York, NY, USA

Ralph V. Shohet, MD

Assistant Professor of Medicine

Division of Cardiology

The University of Texas

Southwestern Medical Center at Dallas

Dallas, TX, USA

Fred Slogoff, MD

Hypertension Section, Cardiovascular Institute

Mount Sinai School of Medicine

New York, NY, USA

Donald A. Smith, MD, MPH

Assistant Professor of Medicine and Community Medicine

Director, Lipids and Metabolism Section

Cardiovascular Institute

Mount Sinai Medical Center

New York, NY, USA 
Christodoulos I. Stefanadis, MD Associate Professor of Cardiology Department of Cardiology Hippokrateion University Hospital National University of Athens Athens, GREECE

Peter H. Stone, MD Assosiate Professor of Medicine Harvard Medical School

Co-Director, Sammuel A. Levine Cardiac Unit

Director, Clinical Trials

Cardiovascular Division

Brigham \& Women's Hospital

Boston, MA, USA

Farris K. Timimi, MD

Cardiovascular Division

Brigham and Women's Hospital Harvard Medical School

Boston, MA, USA

Henry H. Ting, MD

Cardiovascular Division

Brigham and Women's Hospital Harvard Medical School

Boston, MA, USA

Marina G. Toutouza, MD

Cardiovascular Research Laboratories Hippokrateion University Hospital Athens, GREECE

Pavlos K. Toutouzas, MD Professor and Chairman Department of Cardiology Hippokrateion University Hospital National University of Athens Athens, GREECE
Lampros Vlahos, MD

Professor and Chairman

Department of Radiology

Aretaieion University Hospital

University of Athens National

Athens, GREECE

Eric Wasserman, MD

Hypertension Section,

Cardiovascular Institute

Mount Sinai School of Medicine

New York, NY, USA

\section{R. Sanders Williams, MD}

Distinguished Professor,

Chair in Cardiovascular Diseases

Chief, Division of Cardiology

The University of Texas

Southwestern Medical Center at Dallas

Dallas, TX, USA

Paul G. Yock, MD

Associate Professor of Medicine

Stanford University School of Medicine

Director, Center for Rersearch in

Cardiovascular Interventions

Stanford University Medical Center

Palo Alto, CA, USA

Barry L. Zaret, MD

Robert B. Berliner Professor of Medicine

Professor of Diagnostic Radiology

Chief, Section of Cardiovascular Medicine

Yale University School of Medicine

New Haven, CT, USA 